\title{
LOS VALORES SOCIALES DE LA CREATIVIDAD PUBLICITARIA
}

\author{
Isidoro Arroyo Almaraz \\ Profesor de Creatividad Publicitaria. Universidad Rey Juan Carlos. \\ e-mail: isidoro.arroyo@urjc.es
}

\begin{abstract}
Resumen
La creatividad utiliza los valores tradicionales, herederos de las virtudes y los pecados, para resolver necesidades relacionadas con el consumo. En este artículo queremos mostrar que los pecados y las virtudes se utilizan, tanto de forma instrumental como de fin en sí mismo. Los anuncios promueven y animan ideas relacionadas con las virtudes y los pecados mostrando, en algún grado, formas individuales de comportamiento a través de ellas. Las virtudes se convierten en pecados que se desvirtúan desde la parodia, desde la lógica de la desmitificación. Los pecados se convierten en virtudes que dinamizan el deseo, y que favorecen el aprendizaje a través de las marcas
\end{abstract}

\section{Palabras clave}

Valores sociales - Creatividad - Publicidad - Virtudes - Pecados

\begin{abstract}
The creativity uses the traditional values, proceeding of the virtues and the sins, to solve needs related to the consumption. In this article we want to show that the sins and the virtues are in use, so much of instrumental form, as an purpose. The advertising promote and encourage ideas related to the virtues and the sins showing, in some degree, individual forms of behavior across them. The
\end{abstract}


virtues turn into sins that transform from the parody, from the logic of the debunking. The sins turn into virtues that stir the desire into action, and that favor the learning across the marks.

\section{Key words}

Social values - Creativity - Advertisement - Virtues-Sins

"¿Sólo existen siete pecados capitales? Pero si yo he cometido muchos más." Jim Morrison, líder del grupo The Doors (1943-1971)

\section{Introducción}

La creatividad publicitaria juega un papel importante en la búsqueda de soluciones a las necesidades sociales. Éstas se empiezan a resolver cuando las percibimos como valores comunes, porque nos sensibilizan hacia el mundo que nos rodea. Los valores son estados de deseo que nos ayudan a discernir lo que está bien de lo que está mal: "essentially desired states of affairs. They help people define what is good and what is bad” ( Zaltman and Walledorf 1983, pp-431).

Las personas usamos los valores para juzgar el mundo que nos rodea. Así, por ejemplo, valoramos positivamente a las personas que leen. La consideración de la lectura como una necesidad en la sociedad de la información, la convierte automáticamente en un valor. La determinación de ese valor, impone la exigencia de mejorar el nivel de lectura. De manera que, al convertir la lectura en algo valorado, transformamos la necesidad inicial de leer, para tener criterio en la sociedad de la información, en el deseo hacia la lectura. Este deseo nos motivará hacia la lectura y la elegiremos antes que a otros medios de información con más facilidad de acceso

Sabemos que las necesidades humanas son las mismas en todos los tiempos. Las necesidades no cambian, cambian los valores. Pero no sabemos qué papel juega la publicidad en ese cambio de valores. Y es aquí donde queremos situar el objeto de nuestra investigación.

Tradicionalmente, el debate ha estado centrado entre los partidarios de considerar que la publicidad reflejaba el mundo de valores existentes, y los partidarios, que consideraban que la publicidad, ejercía una enorme influencia en la creación de nuevos valores y en la destrucción de los valores tradicionales. 
La posición tradicional sobre los efectos de la publicidad en los valores, ha considerado que la publicidad reflejaba los valores sociales de la sociedad, tanto positivos como negativos (Sissors, 1978; Greyser 1972; Leiss, 1986).

La posición crítica, ha situado el objeto de estudio en la enorme fuerza de la publicidad para crear nuevos valores (Fox, 1984, Garret, 1981).

Se abre una tercera vía que considera que la publicidad es un espejo que distorsiona la realidad, exagerando algunos valores y desmitificando otros ( Pollay, 1986, Schudson, 1984, León, 2001).

El uso de tecnologías de la información y la comunicación, que multiplican el consumo de información, también contribuyen a esta cultura de la exageración carnavalesca de los valores, convirtiéndonos en personas necesitadas de mucha estimulación. Por lo que aceptamos, con gusto, todos los discursos que nos aportan nuevas emociones y nos ayudan a mantener los niveles de activación o arousal, que necesitamos en nuestra vida diaria para competir en el mercado laboral.

Ocurre que, cuando no tenemos la activación adecuada a nuestras expectativas, bien por demasiado baja bien por demasiado alta, nos sentimos profundamente incómodos; aburridos, en el primer caso o temerosos, en el segundo.

La creatividad publicitaria capta de inmediato estas nuevas necesidades de búsqueda de sensaciones, porque pulsa la realidad constantemente a través de la investigación y se instala en la cultura del espectáculo, respondiendo con sus mensajes emotivos y burlescos, a la necesidad de información, persuasión y estimulación de sus públicos objetivos.

Para ello, recurre con mucha frecuencia al pensamiento mágico; ya que, por una parte, trasciende y crea identidad grupal. Y, por otra, instala en el imaginario de los consumidores, un universo de beneficios que se pueden conseguir cuando se poseen las marcas.

No nos extraña la facilidad con la que la publicidad desmitifica lo respetable: la ciencia, el arte, la religión; a la vez que santifica a la propia publicidad; connotando sus mensajes de sorpresa, fascinación, miedo, lujo, sacrificio, emoción, éxtasis, mitología, valores inmateriales, ritos y crea, en torno a sí misma, una comunidad de creyentes en el consumo y en su capacidad para redimirnos del nuevo pecado original, que para la publicidad consiste en no poseer ninguno de los productos que se ofrecen. (León, 2001, 59) 


\section{El modelo axiológico Siete pecados-Siete virtudes}

Se hace necesario identificar y sistematizar los valores presentes en la publicidad para saber, si la presencia deformada de valores en la publicidad: unas veces exagerando algunos valores y otras desmitificando los valores tradicionales, ejerce alguna influencia social, que nos permita predecir alguna conducta humana.

Para ello hemos recurrido, como punto de partida, al modelo de análisis basado en la conocida lista de valores tradicionales: "Los siete pecados capitales y las siete virtudes cardinales", ya sugerido por Holbrook y Pollay (1986 y 1987).

Este modelo no surge en el ámbito de la publicidad como una heurística más, sino que procede de la filosofía griega: Platón y Aristóteles y se ha extendido, pulido y definido a lo largo de los siglos en la cultura occidental. (Belk, 1982).

La publicidad los ha utilizado abundantemente, desde dos perspectivas distintas:

Primero, de forma instrumental, para alcanzar otros objetivos porque, como señala Manuel Vicent: "La humanidad estaría todavía en las cavernas de no ser por estas siete grandes turbinas del espíritu que la han empujado con enorme fuerza hacia lo alto de la historia. Soberbia, avaricia, lujuria, ira, gula, envidia, pereza (...) estos pecados capitales son los motores de la creación de riqueza”. (“Exorcismo”,EP 25-09-05).

Una visión crítica, actualizada y desenfada de lo que“los siete pecados capitales” representan en nuestros días, editada por Paidós (2005), nos recuerda la vigencia de estos “motores de la historia” en la evolución de nuestras economías liberales.

Y una visión humanista, desenfadada e histriónica, llega a los escenarios de nuestros teatros bajo el título de “Amor y otros pecados” dirigido por Javier Veiga e interpretado por el mismo Veiga y Anna Rayo que, utilizando instrumentalmente los siete pecados capitales, nos presenta hasta siete parejas diferentes, que reflexionan sobre las relaciones entre hombre y mujer.

Segundo, como una finalidad en sí misma, de manera que a veces la creatividad publicitaria ha promovido los valores negativos -los pecados-, haciéndolo de manera distinta, según en qué época:

En sus inicios, entre 1890 y1930, construía sus mensajes a base de mostrar modelos de conducta de otras personas, que se convertían, por su presencia masiva, en modelos sociales de referencia que orientaban y predecían la conducta social de sus públicos. En esta época los valores dominantes eran la sensibilidad o la apertura hacia las formas de actuar de los demás.

A partir de 1930 hasta 1960, la creatividad publicitaria se fue llenando de otros valores más directamente relacionados con intereses personales: la avaricia, la lujuria, la envidia, etc. 
A partir de esa época y hasta la actualidad el uso de los pecados y las virtudes han ocupado, en diferente grado, buena parte de la parrilla de valores que la publicidad ha utilizado en la creatividad de sus mensajes.

En un estudio de Pollay (1984) llegaron a las siguientes conclusiones: El 38\% de los anuncios en revistas entre 1900 y 1980 reflejaban la sabiduría como tema principal; el sexo y la vanidad en un 16\% y el estatus en un $13 \%$.

En otra investigación (Tanaka, 1984) se encontró que la sabiduría se reflejaba en un 8\% de los anuncios gráficos en revistas; el estatus y la sexualidad en menos de un $1 \%$.

En un estudio hecho con anuncios televisivos dirigidos a niños se encontró que el 58\% de estos anuncios incluían valores pro sociales, tales como la amistad (29\%), el afecto (31\%). Ahora bien, los autores de esa investigación no aclararon si el 42\% restante de los anuncios dirigidos a niños incluían valores antisociales.

De todos estos resultados, no es fácil obtener una conclusión definitiva sobre la influencia de los pecados y las virtudes en los valores transmitidos por la publicidad. Clarke L.Caywood y Frederick W. Langrehr (1995) se han ocupado de estudiar las contribuciones teóricas que se han hecho en investigaciones originales sobre este modelo y concluyen que, además de la publicidad, que es un agente importante que interviene en al difusión de los siete pecados y siete virtudes, existen otras influencias sociales como la escuela y la familia que también influyen.

\section{Los pecados y las virtudes, una vía heurística de procesamiento de la publicidad}

La transmisión de valores sociales no es solamente competencia de los medios de comunicación y de forma especial de la publicidad. También dependen de la interpretación que el receptor del mensaje haga del mismo.

Los autores citados anteriormente consideran que el valor de un anuncio, también depende del valor que le atribuye el receptor: "the meaning of an ad, according to semiotic or sign análisis, is bases upon the interpretatio of the person seeing or hearing the ad”. (Langrehr y Cauwood, 1995, 33)

De los cuatro modos de significar de un anuncio descritos por Morris: identificación, designación, valoración y prescripción; es a nuestro juicio, el de valoración, el que se escapa al control del creativo publicitario, dejando una buena parte de su eficacia al control e interpretación del receptor, ya que "the meaning of advertising is based on the interpretation of the person seeing and/or hearing the ad and not 
only the interpretation of the people developing the ad”. El receptor, en cualquier caso, siempre interpreta el mensaje, pero no siempre lo hace en la línea que conviene al anunciante. La eficacia de la comunicación del anunciante va a depender de la interpretación correcta de los signos y símbolos connotados del anuncio, que como señalara Barthes (1988): “connotative meaning of ads are based on the observer's background (...) different observers may ascribe different connotative meanings to he same ad.”

Sabemos, por la investigación realizada por Langrehr y Cauwood (1995), que un redactor publicitario, un anunciante, un líder religioso y/o ético y un consumidor independiente pueden interpretar un anuncio de forma diferente. De manera que, los valores de los anuncios publicitarios dependen de los factores contextuales y biográficos del observador que los analiza.

No sabemos, hasta qué punto las opiniones y creencias sobre la publicidad en general, afectan a la percepción de los valores que ésta connota con sus anuncios. En la investigación de Langrehr y Cauwood, (1995) era previsible que tanto el líder religioso como el director creativo, ambos más proclives a favorecer los valores del consumidor; coincidirían en sus interpretaciones semióticas sobre la presencia de valores en los anuncios. Sin embargo, el religioso y el consumidor otorgaron a los anuncios una mayor presencia de pecados y virtudes que el creativo publicitario aunque, a menudo no estaban de acuerdo y, cuando uno interpretaba un valor como pecado el otro lo hacía como virtud. Quizás, como concluyen los autores citados, “el bosque no dejara ver los árboles” y el creativo publicitario, que no intentaba comunicar virtudes o pecados, sino promesas y beneficios, no percibía su presencia.

Nosotros a través de un análisis de contenido, apoyándonos en esta concepción poliédrica de la presencia/ausencia de pecados y virtudes en la publicidad, hemos observado que la publicidad utiliza los pecados capitales, desde la lógica de la desmitificación de la virtud; y lo hace contraponiendo la virtud al pecado y el pecado a la virtud.

\subsection{Las virtudes de los pecados}

"La virtud no consiste en abstenerse del vicio, sino en no desearlo." George Bernard Shaw Dramaturgo inglés (1856-1950)

\section{La soberbia}

“El amor propio es más arrogante que ciego: no nos oculta nuestros defectos, nos convence de que escapan a los ojos de los demás”. Samuel Jonson. Erudito y moralista inglés (1709-1784) 
La humildad queda eclipsada ante la fuerza arrogante de la soberbia. La creatividad publicitaria utiliza, para mostrar la soberbia, la arrogancia de personajes llenos de presunción. Un buen ejemplo, lo encontramos en el anuncio de páginas amarillas que nos mostraba la soberbia de la monja que sugiere a otra hermana que use el índice en el anuncio de páginas amarillas. De manera que la virtud de la humildad, queda superada por el pecado de la soberbia en un contexto extremo, como es el diálogo entre dos monjas. La búsqueda de información es tan sencilla cuando se utilizan las páginas amarillas que no saber utilizarlas supera la paciencia de la hermana que responde con soberbia, transgrediendo la virtud de la humildad, que se supone sobrada en cualquier monja.

La soberbia estimula la realización de un trabajo bien hecho, allí donde es posible. Convierte los problemas en soluciones posibles. Con la soberbia se consigue lo que se desea, porque lo que importa es ser el mejor.

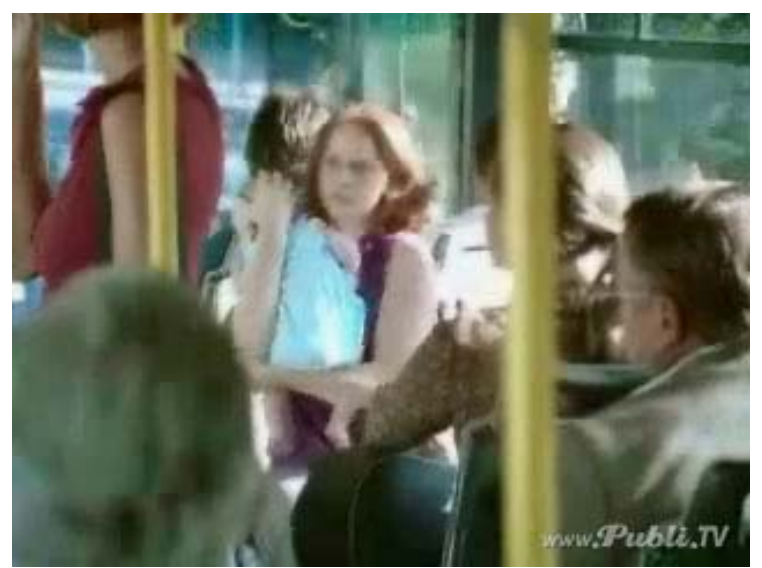

La soberbia del personaje consigue que el niño llore a buen ritmo, con un Ilanto razonablemente acelerado.

\section{La gula}

"El pecado de la gula está reservado a los ricos. Los pobres tienen que conformarse con rebañar los platos." Lillian Hellman. Escritora estadounidense (1905-1984)

La templanza pasa desapercibida ante la apisonadora de la gula; que se muestran en los anuncios de alimentación, donde se come abundantemente, o en la presencia de anuncios con productos que estimulan la glotonería: “Minute Maid, estallido de sabor”; “Chocolates Valor, placer adulto”; “Solano fresa y nata, el nuevo placer sin límite”.

La gula estimula la búsqueda del placer en la comida. Convierte lo bueno en placentero. 


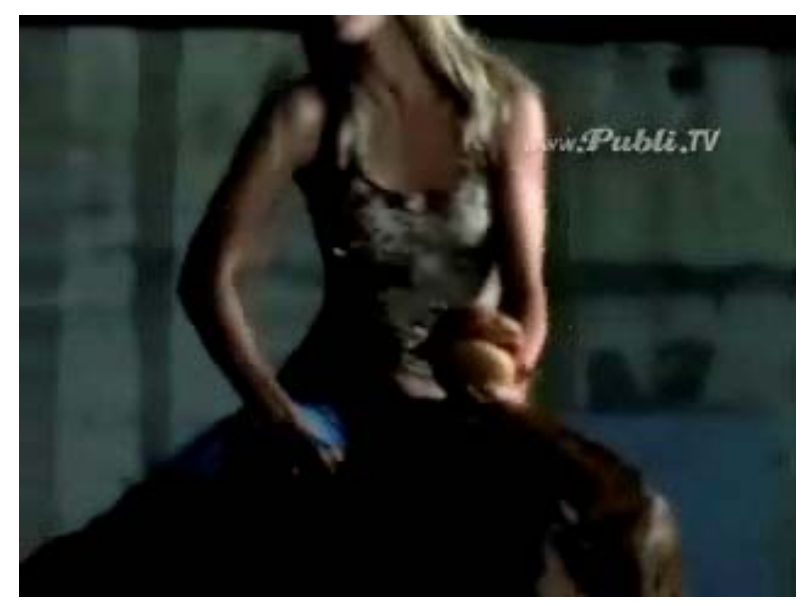

La lujuria, de la mano de los movimientos sensuales de la modelo sobre el toro mecánico, facilita visualmente el mismo placer que nos proporcionaría comernos con gula esa gran hamburguesa.

Es el caso también del anuncio de las monjitas que confraternizan con el diablo tentadas por los turrones El Almendro. El diablo aparece siempre como un personaje relacionado con la tentación irresistible. Así por ejemplo, los helados Miko nos lo recordaban con su slogan: “Tú también caerás”.

\section{La lujuria}

"La lujuria nunca duerme. No me importa, yo soy insomne."

Totó. Cómico y actor italiano (1898-1967)

La castidad queda desmontada por el poder trasgresor de la lujuria. La lujuria se presenta creativamente bajo un exceso de estimulación sexual. La tentación del deseo sexual. Así lo apreciamos en anuncios, como el de las hermanitas, tal vez novicias, que lujuriosas se debaten con la hermana superiora si pegaban el pene de una escultura hacia arriba o hacia abajo en el galardonado anuncio de pegamento Rubber, para, con todo ello, mostrar como el deseo de poseer o disfrutar el producto lleva a los más virtuosos a pecar.

La publicidad utiliza la lujuria porque ésta se convierte en un motor que activa el deseo de poseer el objeto de satisfacción del deseo y moviliza para su consecución. 


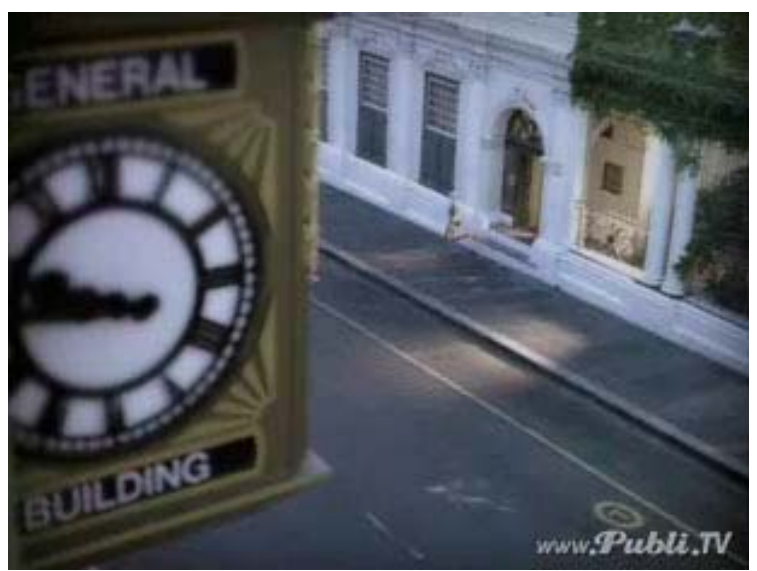

La belleza de la modelo junto con el rótulo de la camiseta: "Men only want sex", se convierte en una promesa creíble de satisfacción del deseo sexual, como la bebida satisfaría el deseo de hidratación de cualquier deportista.

El exceso de sex appeal en la publicidad está teniendo, en muchos países, la proliferación de anuncios sexistas que exhiben violencia hacia las mujeres o que las presentan como meros objetos de deseo (Para una revisión del tema , ver: Jean J. Boddewyn ,1991).

\section{La avaricia}

“¿Qué es la avaricia? Es vivir con pobreza por temor a la miseria”. San Bernardo (1090-1153).

Este pecado se ha puesto de moda en los hogares alemanes, que ahorran como nunca desde la reunificación (...) Sin embargo esta furia ahorradora tiene consecuencias negativas para la marcha de la economía. La demanda interna se ha venido abajo. (...) Por eso una empresa de publicidad de Hamburgo ha inventado un eslogan que causa furor: "La avaricia mola” (Geiz ist geiiil!!!) con el que los alemanes se lanzan a comprar desenfrenadamente todo tipo de electrodomésticos. Como señala José Comas. “La empresa de publicidad de Hamburgo que inventó el eslogan se ha apuntado un gran triunfo porque está en boca de todos. Diputados lo citan en discursos ante el pleno del Parlamento federal (Bundestag). Aparece en sesudos editoriales de la prensa escrita. Pequeños comercios lo pegan a la puerta para invitar a comprar.'(EP 202-2005)

La generosidad queda descompuesta por la avaricia. La creatividad publicitaria presenta el deseo de poseer cada vez más cosas, más de las que son necesarias.

La avaricia se muestra bajo el deseo de poseer más dinero o en mejores condiciones. Por ejemplo, mayores intereses bancarios (ING Direct), la obtención de créditos fáciles con una simple llamada de teléfono (Cofidis), o la obtención de dinero a fuerza de explotar a una mascota, como en el siguiente anuncio. La avaricia se pone al servicio de la solución a un problema financiero. 


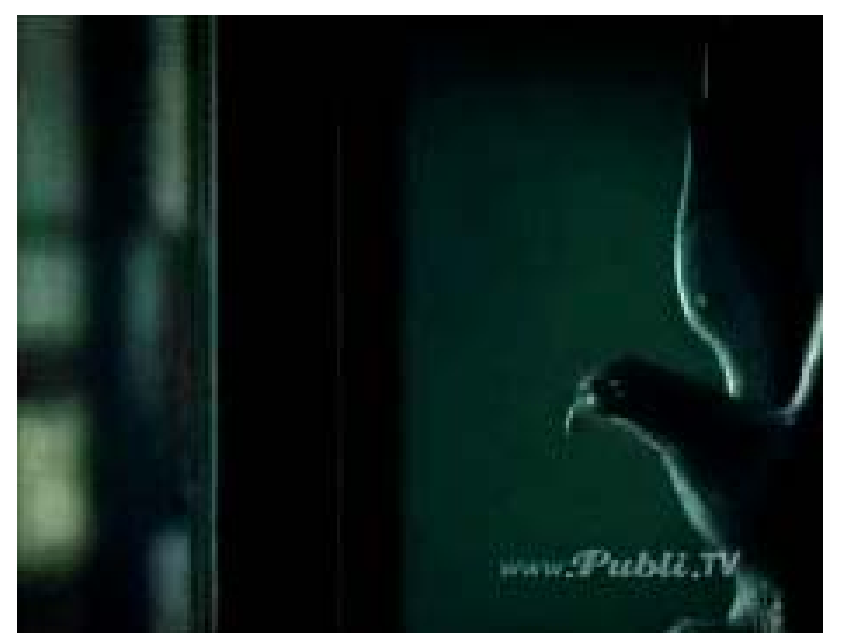

En este anuncio la avaricia del protagonista, que piensa que va a ganar un millón gracias a su mascota, le lleva a someterla a un duro entrenamiento. Al final la avaricia rompe el saco.

La avaricia aparece también bajo el deseo de que los productos de consumo sean superabundantes o, en su defecto de gran tamaño: Plaza Mayor, un gran parque de atracciones; Hipermercados Alcampo: Fulminamos los precios, También existen fórmulas retóricas por acumulación de adjetivos que redundan en la valoración del producto: “Cambia tu punto de vista. Más alto, más robusto, un nuevo concepto de automóvil. Nuevo FordFusión.”

La avaricia también la encontramos en la petición ostensible de poseer objetos materiales .La función conativa de la publicidad y el modo imperativo se dirigen hacia ese fin: "Un cacao que te seducirá cada día sorbo a sorbo. Pruébalo. Disfrutará como un niño. Nuevo cacao Nestlé Selección. Más cacao, más placer".

La avaricia aparece bajo el paradigma dominante de la no limitación en la adquisición de bienes tangibles: “Cómprelo”.

\section{La ira}

"Las consecuencias de la ira son siempre muchísimo peores que las causas que la provocan." Marco Aurelio. Empreador romano (121-180)

La paciencia queda derribada por la ira. La creatividad publicitaria la presenta a través del sentimiento hostil hacia algo o hacia alguien. Por ejemplo, McEnroe aparece enfadándose, como lo hacía cuando jugaba al tenis, y la toma con un policía, el juez de silla, que quiere multarle porque ha aparcado su 
flamante SEAT Altea fuera del límite de la línea permitida.” En el juego metafórico de la competición, se muestra la ira del que fue gran jugador de tenis.

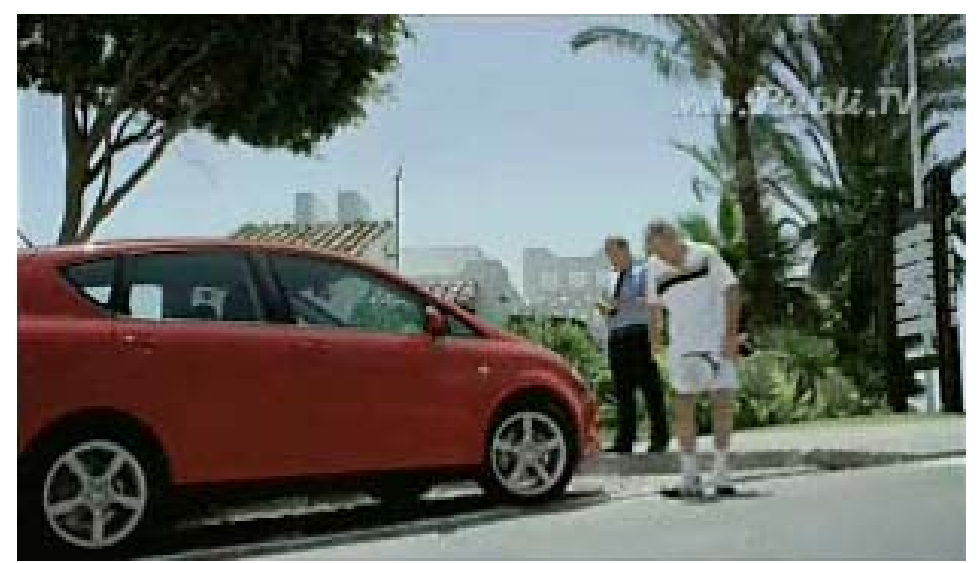

La ira de McEnroe pone en escena y representa el gran carácter del nuevo SEAT Altea.

Este sentimiento de descontento hacia algo o hacia alguien, a veces se utiliza para romper o destrozar algo de la competencia. La ira se pone al servicio de la expresión y connota la gran relación de belleza, calidad y precio en los producto Cherokee.

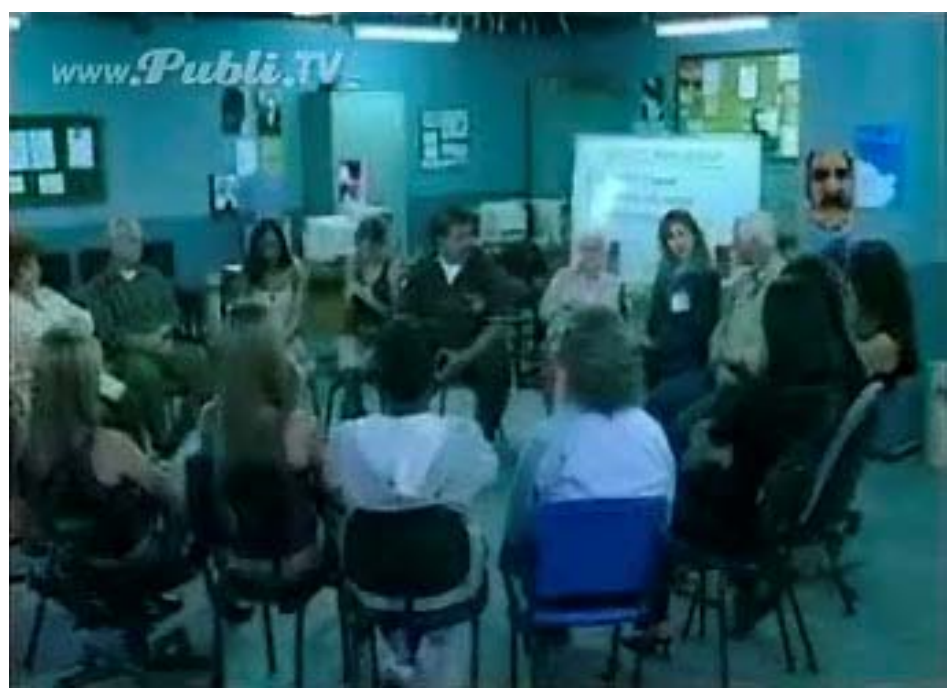

Naomi Campbell dramatiza la ira que siente porque su gusto le lleve a ponerse un vestido barato.

\section{La envidia}

“El tema de la envidia es muy español. Los españoles siempre piensan en la envidia, y para explicar que algo es bueno, dicen: es envidiable”. Jorge Luis Borges (1899-1986) 
La caridad queda rebajada por la envidia. La creatividad publicitaria la presenta, entre otras maneras, como: celos por el placer o el éxito de otros. Por ejemplo en el anuncio de Ikea: “ahora ya puedes ser la envidia de todos tus compañeros y salir del trabajo antes de tiempo todos los días”.

La envidia despierta el deseo por conseguir lo que los demás disfrutan, a la vez que transforma ese deseo, en un sentimiento de reconocimiento hacia los demás, por lo que pueden disfrutar.

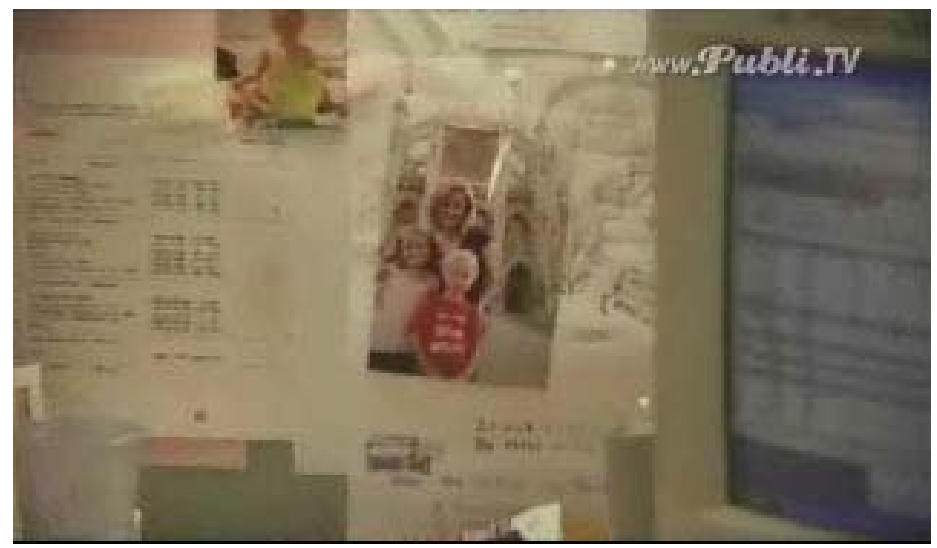

Los compañeros de trabajo sienten envidia porque el protagonista finaliza su jornada de trabajo antes que los demás. En vez de odiarle por ello, le aplauden.

Pero la envidia también transforma el deseo, en un descontento por las posesiones o ventajas que tienen los demás. Por ejemplo, en el anuncio de Bembo: "El chico gracias a esa gran hamburguesa va a conseguir ser la envidia de "casi" todos los hombres” y de las mujeres.

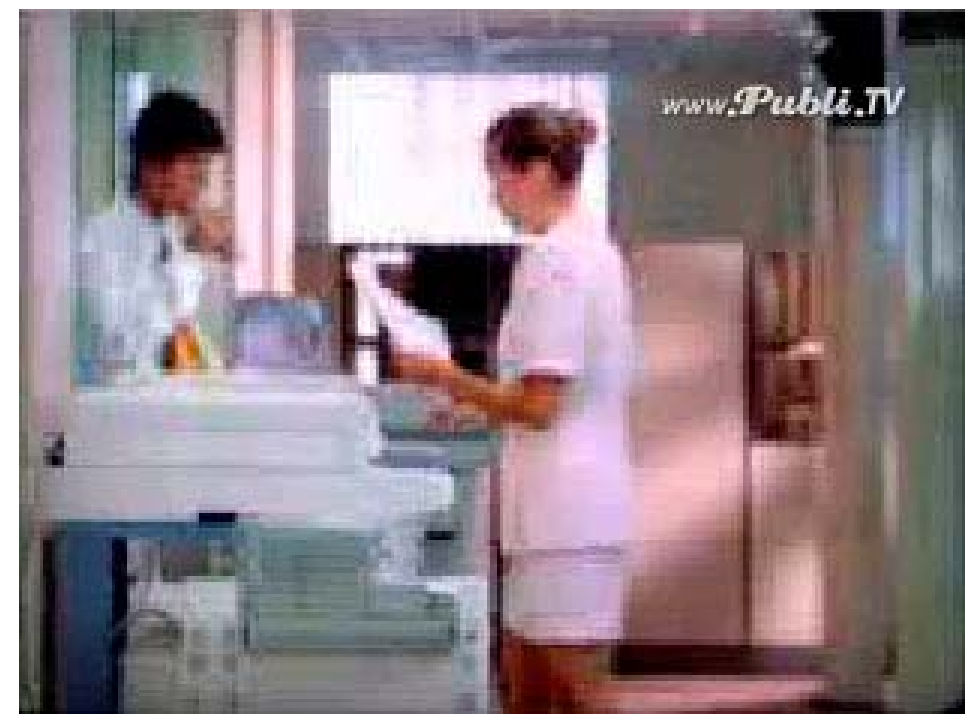

El protagonista despierta la envidia del sexo opuesto, capaz de cualquier trasgresión para satisfacer su deseo. El deseo de comer un trozo de hamburguesa despierta la atracción hacia el chico. La chica, a través del beso al chico, satisface su doble deseo: hacia el chico y hacia la hamburguesa. 
La creatividad publicitaria también utiliza la envidia, como un sentimiento de interés hacia los procedimientos que los demás realizan para obtener sus placeres. Como se puede observar, por ejemplo, en el siguiente anuncio de Nestlé”

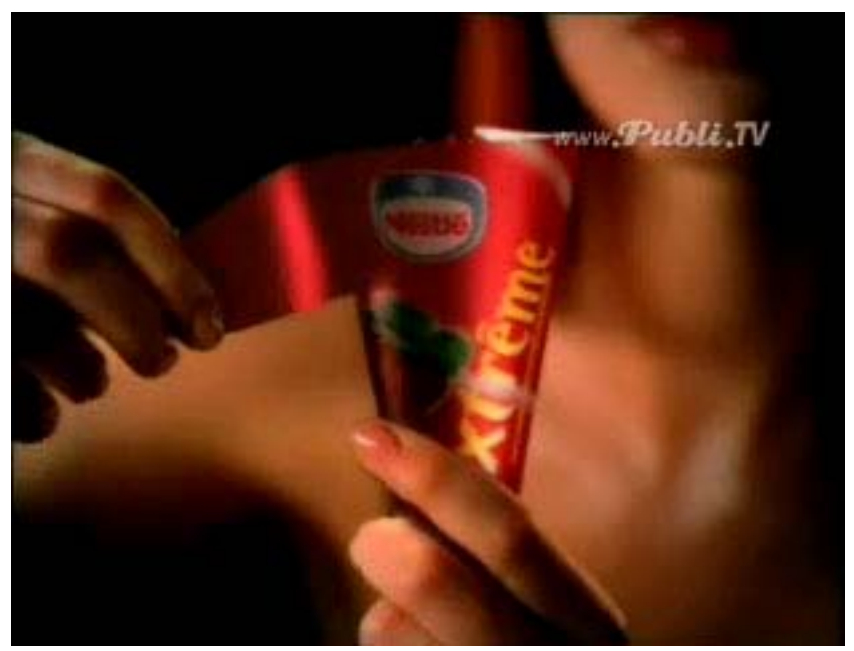

La envidia estimula el deseo de poseer el helado. La envidia multiplica los beneficios del helado.

O, como reza el copy del anuncio “Damas de Blanco: Escenas en el Mar” de Planeta Directo Selección,: “ Cada lienzo se presenta en un lujoso marco de estilo francés (...) Sin duda, despertará la envidia de todas sus visitas”.

Se diferencia de la avaricia en que la envidia esta dirigida a una persona o un grupo específico que posee alguna ventaja o producto.

\section{La pereza}

"Es mentira que sea un perezoso. Lo que me ocurre es que no me gusta levantarme temprano." Groucho Marx Actor y cómico estadounidense (1890-1977)

La diligencia queda eclipsada por la pereza. La creatividad publicitaria la presenta como personajes con poco inclinación al trabajo o que se presentan a sí mismo como un modo de vivir sin ocupaciones, ni preocupaciones.

La creatividad publicitaria convierte a la pereza en un valor social positivo, ya que con el poco esfuerzo que conlleva la pereza, se puede ayudar mucho, ya que no es difícil donar lo que no te ha costado tanto ganar. 


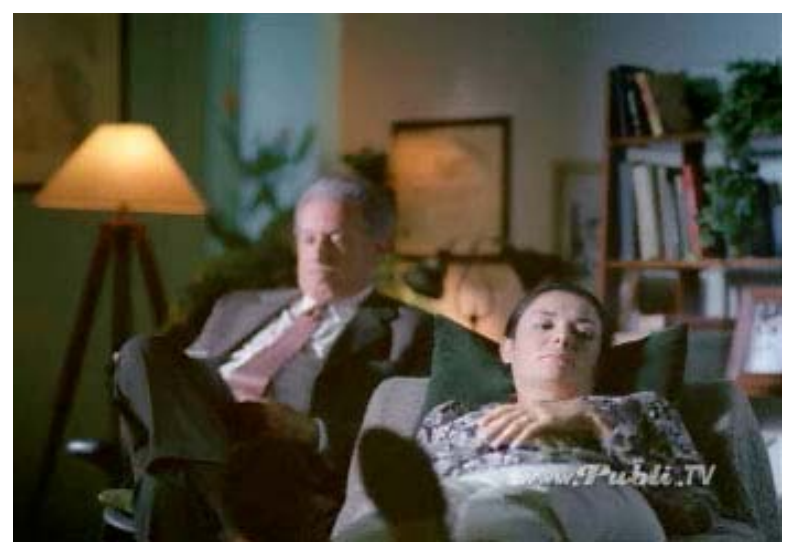

El anuncio muestra con que poco esfuerzo -casi perezoso- se puede acabar con las desigualdades del mundo.

\subsection{Los pecados de las virtudes}

"Es mejor permanecer en silencio y parecer estúpido que abrir la boca y confirmarlo." Groucho Marx. Actor y cómico estadounidense (1890-1977)

\section{La moderación}

“La moderación es el mejor de los bienes”. Rubén Darío.

Aparece siempre relaciona con la moderación en la comida, en la bebida (Bebe con moderación, es tu responsabilidad) y en acciones personales, donde la moderación de los protagonistas se reviste de dominio de sí mismo. Los personajes demuestran un control de la situación y una moderación en su forma de actuar.

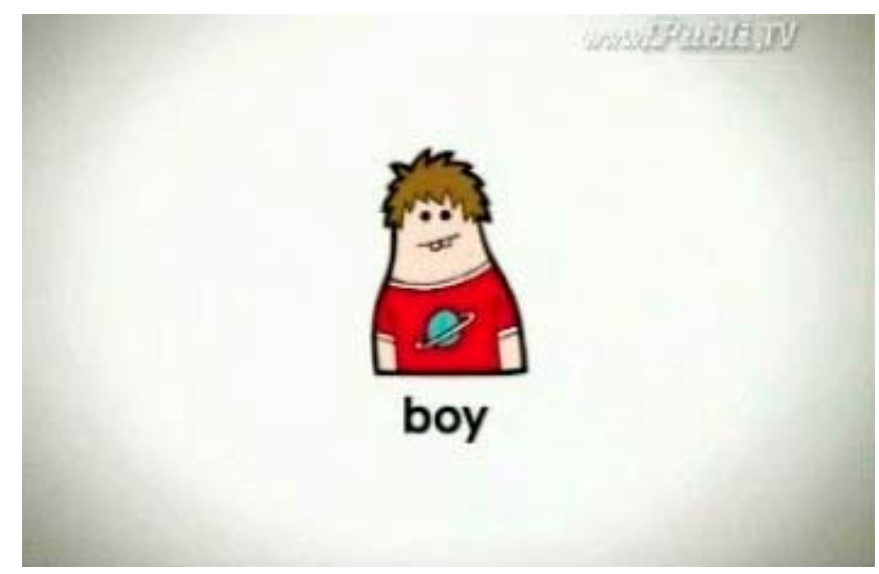

Cuando la vida se complica mucho, el gesto sencillo y moderado comerse una simple hamburguesa nos puede evitar males mayores. 
Su pecado es que un gesto moderado, la moderación en el comer y en el beber, se convierte por la hipérbole de la imagen en gula.

\section{La sabiduría}

"La sabiduría está definida como la "conducta prudente de la vida". Y la prudencia es una "virtud que consiste en discernir y distinguir lo que es bueno o malo para seguirlo o huir de ello”.

Diccionario de la Lengua Española.

La creatividad publicitaria dibuja la sabiduría bajo la fórmula de buen juicio o criterio. Es decir, estimulando buenos juicios o buenos aprendizajes con las marcas, también se incita al uso del buen criterio.

Su pecado es que a veces no se elige lo más conveniente porque la tentación de “pecar” es muy fuerte. Cuando esto ocurre, la marca sale ganando.

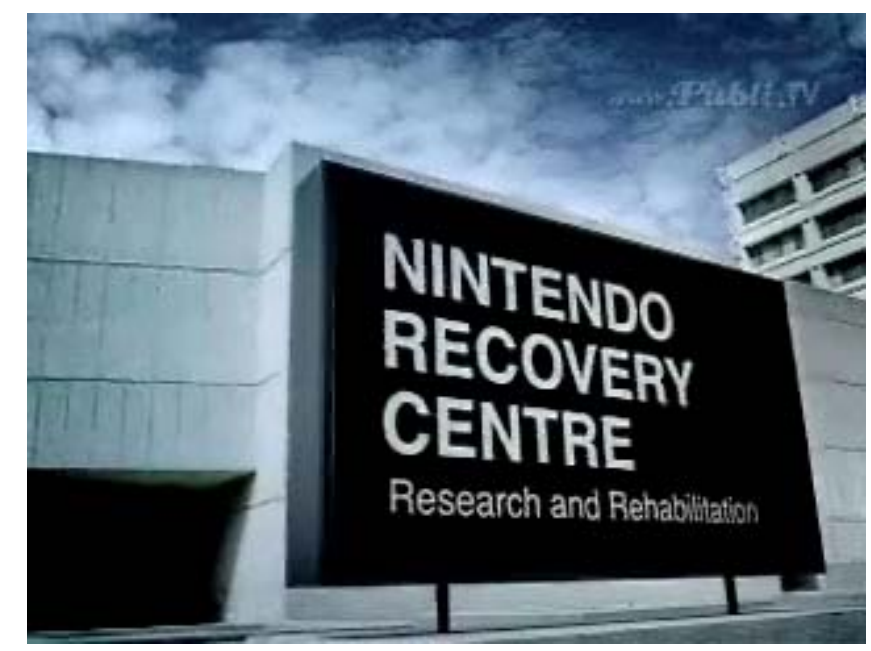

Ninguna elección es tan segura como la que se deriva del deseo.

La publicidad siempre alentará la adquisición de conocimientos a través de la marca que se relacionen con sus ventajas y beneficios. 


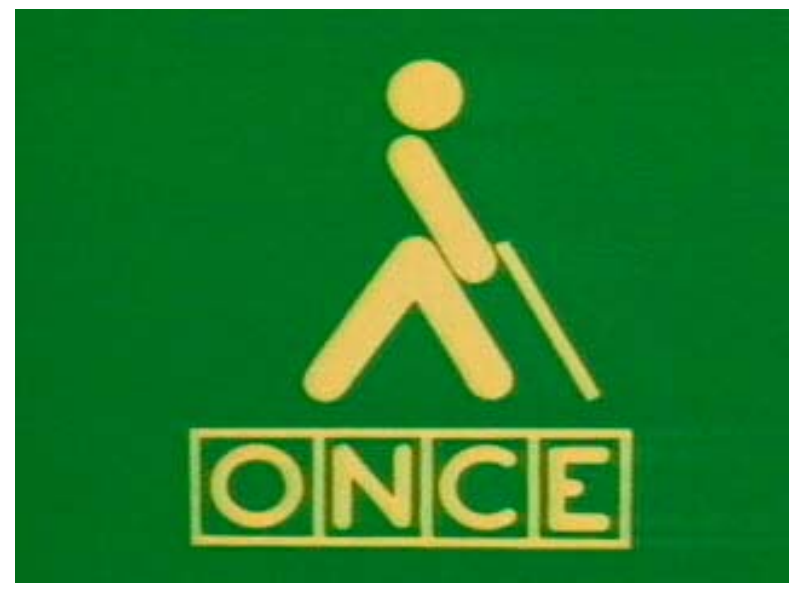

La ilusión de todos los días: transformar la vida de personas ciegas.

La creatividad publicitaria también alienta la justeza de juicio en la elección de pensamientos y fines. El sentido común y la racionalidad aparecen en cualquier toma de decisiones.

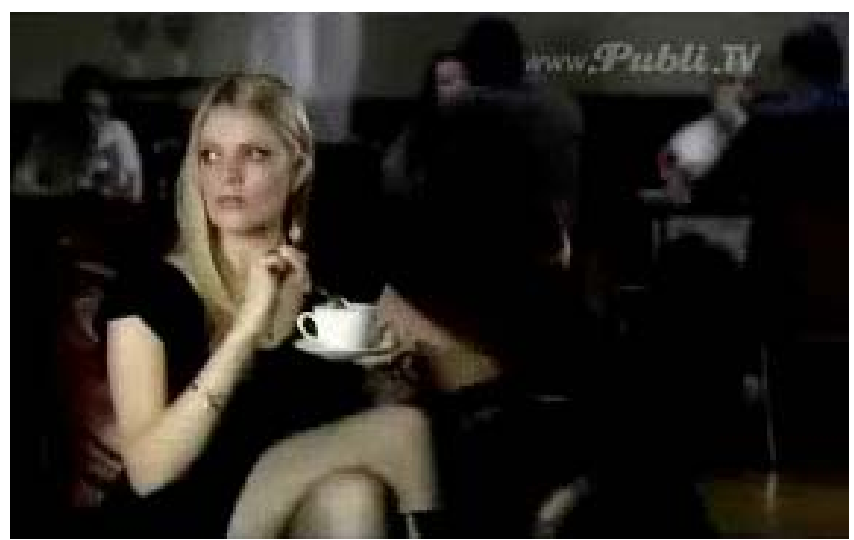

Acostúmbrate a elegir y siempre elegirás lo más conveniente.

\section{La justicia}

“El que decide un caso sin oír a la otra parte, aunque decida justamente no puede ser considerado justo”. Lucio Anneo Séneca

Sin duda es la cualidad más moral de todas las que se muestran en los mensajes publicitarios. Cuando aparece lo hace bajo la fórmula de imparcialidad y de honradez.

Entendiendo la imparcialidad desde el principio de equidad. Es decir, la publicidad estimula la imparcialidad, premiando las acciones justas y reprobando a quienes no las contemplan así.

Su pecado es que a veces la virtud del perdón se transforma en arrogancia. 


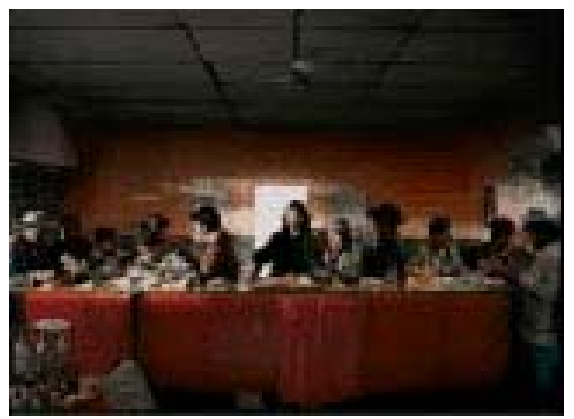

La mayor grandeza de cualquier ser humana es perdonar al que no sabe lo que hace.

Otra forma consiste en no mostrar favoritismos para ganar ventajas personales.

\section{El coraje}

"La ambición es un vicio pero puede ser la madre de la virtud."

Quintiliano.

El valor de la fuerza moral y mental para perseverar y soportar el dolor, el peligro, el miedo o las dificultades. La publicidad contempla el valor y la bravura.

El coraje se beneficia del nuevo diseño de la botella de Pepsi que permite que sea agarrada mejor.

Su pecado es que, un pequeño beneficio, un diseño en la botella, transforma una virtud, el coraje, en un pecado, el riesgo.

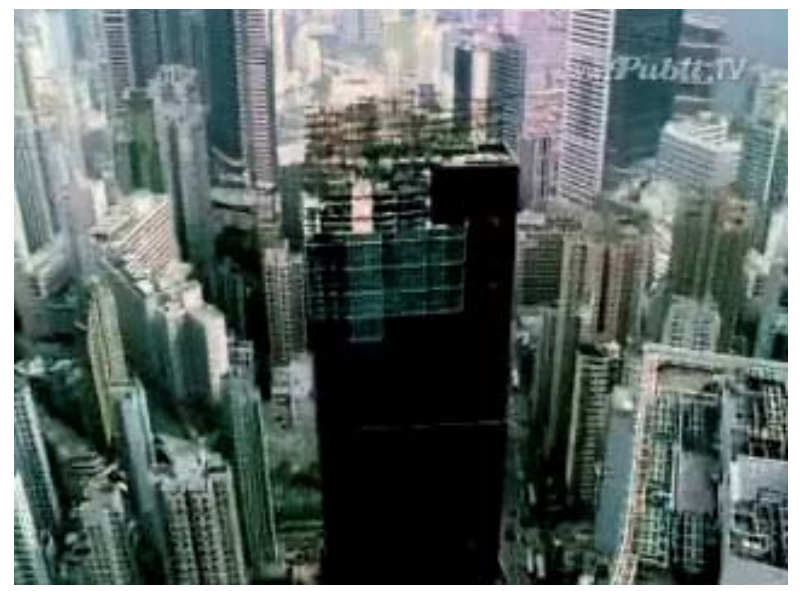

La seguridad de una gran marca ayuda a sobrevivir ante las dificultades. 
La fe

“Da el primer paso en la fe. No necesitas ver toda la escalera, sólo dar el primer paso” Martin Luther King

Entendida como una confianza completa en los grandes ideales, lealtad hacia algo o alguien y aceptación personal de algo como verdadero o real: confianza y confidencia.

Su pecado es que, por ejemplo, una gran virtud como es la fe en un gran equipo, se convierte en el último de los pecados que le quita a uno la vida.

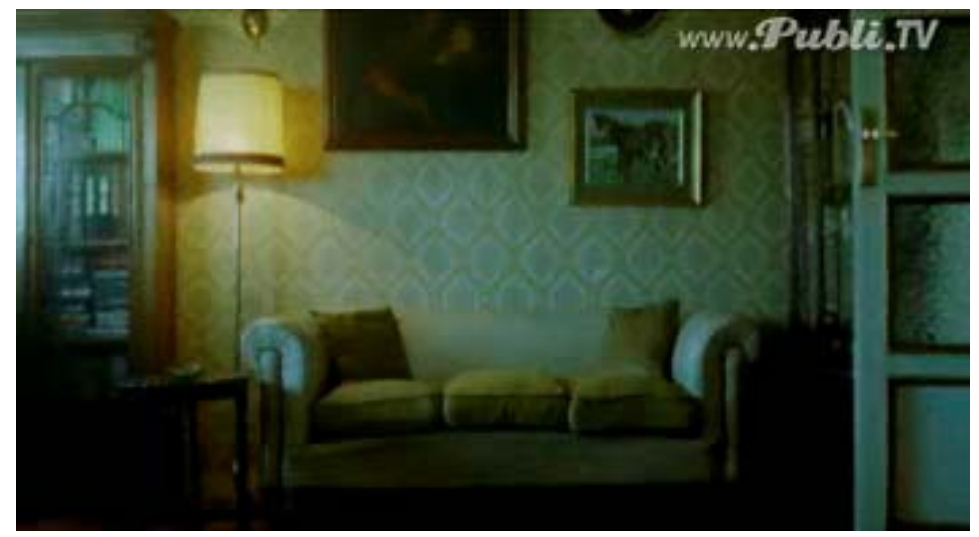

...Pero el puñetero Atleti.

Para reforzar la confianza la publicidad utiliza múltiples mitos: lo fue el monaguillo, en la antigua publicidad de Airtel (ahora Vodafone); el ángel, en la de Verino; la diosa Afrodita, en la de Gala de Loewe, los rituales budistas, en la publicidad de Opel y Citroen, etc. y así provocar imágenes mentales que conmocionan al espectador y provocan su identificación con el producto añadiéndole los valores espirituales de los que carecen los productos y los servicios publicitados.

\section{La esperanza}

"El problema (pecado) de nuestro tiempo es que el futuro ya no es lo que era." Paul Valéry. Poeta y crítico francés (1871-1945)

Sin duda la publicidad alimenta el sentimiento de mejorar mañana. Es decir, expresa la creencia en el mañana que traerá más y mejores cosas. El futuro publicitario es el futuro imperfecto, de manera que las promesas del presente son casi los hechos del futuro. 
“Domicilia tu nómina en Santander Central Hispano y nos ayudarás a curar junto a Médicos Sin Fronteras a un millón de niños sin que te cueste nada”.

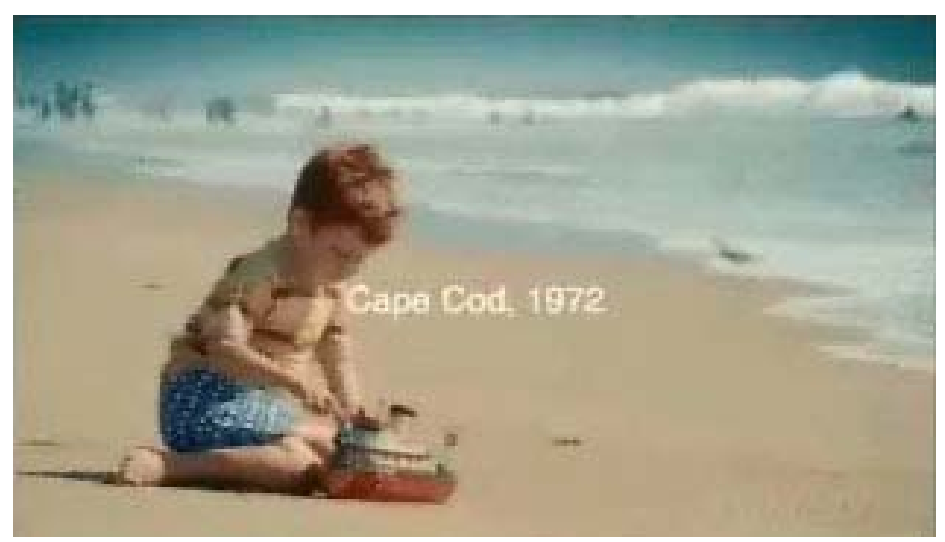

La esperanza de convertir tus sueños en realidad.

\section{El amor}

"El amor es el significado último de todo lo que nos rodea. No es un simple sentimiento, es la verdad, es la alegría que está en el origen de toda creación." Rabindranath Tagore.

Estimula un sentimiento profundo de afecto o relación con alguien. No se trata de un amor físico o sexual. Es la expresión de un sentimiento. Por tanto, también se puede aplicar a animales, mascotas, objetos, etc. Y ¿por qué no a los colores de tu club?

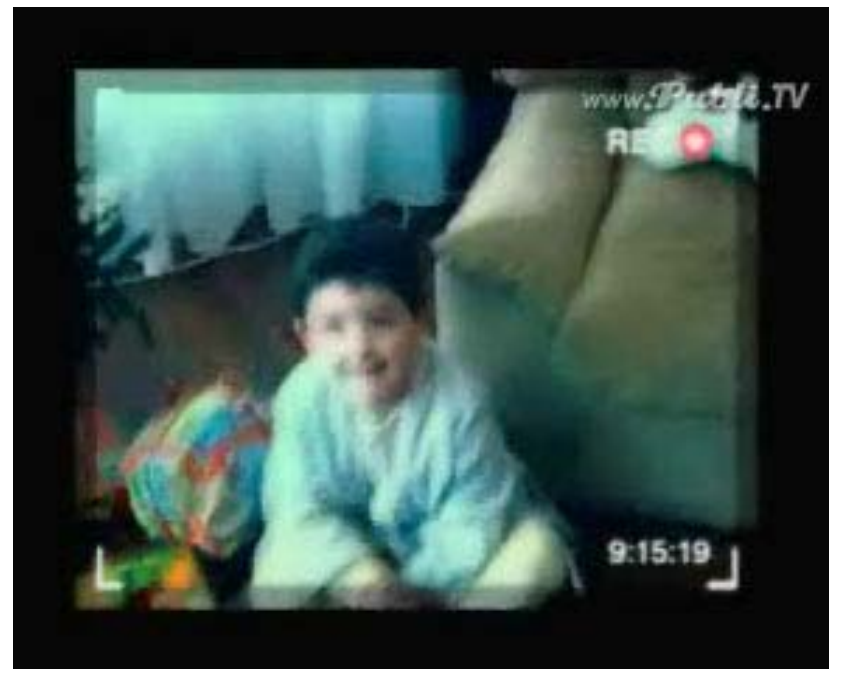

Por amor propio. 
Su pecado es que amar al prójimo, que debiera significar desear y hacer siempre el bien, a veces se resiente porque los bienes o logros de otro reducen nuestra auto-estima.

\section{Conclusiones}

La creatividad utiliza los valores tradicionales, herederos de las virtudes y los pecados, para resolver necesidades relacionadas con el consumo y lo hace, tanto de forma instrumental, como fin en sí mismo.

Los anuncios promueven y animan ideas relacionadas con las virtudes y los pecados mostrando, en algún grado, formas individuales de comportamiento a través de ellas.

Frente a la tesis de que la publicidad promovía sólo valores negativos, se impone cada vez más la convicción de que la publicidad también promueve valores positivos y que, en definitiva, el significado que se le da a los anuncios depende en buena medida de la interpretación personal que cada receptor realiza de las señales que recibe. Por tanto, el valor connotativo de la publicidad se impone al valor denotativo.

Cuando la publicidad utiliza los pecados capitales, lo hace contraponiendo el pecado a la virtud: contra la soberbia, humildad; contra la avaricia, largueza; contra la lujuria, castidad; contra la ira, paciencia; contra la gula, templanza; contra la envidia, caridad; contra la pereza, diligencia y convirtiendo, con ello, a las virtudes en motores de la persuasión al servicio del deseo.

Las virtudes se convierten en pecados que se desvirtúan desde la parodia, desde la lógica de la desmitificación.

Los pecados se convierten en virtudes que dinamizan el deseo, que favorecen el aprendizaje a través de las marcas y, en definitiva, que ayudan a elegir a los consumidores.

\section{Bibliografía}

ARROYO, I. (2002) Ética de la imagen.. Laberinto Comunicación Madrid.

ARROYO,I.(2004), La Creatividad y la razón tecnológica en la argumentación publicitaria. En Creatividad y Sociedad nº 6, págs. 27-34.

BARTHES, R. (1988) The Semiotic Challenge, NEW York: Hill \& Wang. 
BELK, R. W. (1982) Worldly Possessions: Issues and Criticisms en Advances in Consumer Research, Volumen 10, eds. Richard P.Bagozzi and Alice M. Tybout, Provo, Utah: Association for Consumer Research, págs 514-519.

BODDEWYN , J. J. (1991) Controlling Sex and Decency in Advertising Around the World en Journal of Advertising, Volumen XX, nº 4, págs 25-35.

FOX, S. (1984) The Mirror Makers: A History of American Advertising and Its Creators. New York: William Morrow and Co.

GARRET, T.M. (1961) An Introduction to Some Ethical Problems of Modern Advertising.Rome: The Gregorian University Press.

GREYSER, S. (1972) Advertising: Attacks and Counters en Harvard Business Review n 50 págs 22-28 y 140-146.

HOLBROOK, M. B. (1987) Mirror, Mirror, on the Wall,What's Unfair in the Reflections on Advertising? En Journal of Marketing, nº 51, págs. 95-103.

LANGREHR F. W..CAYWOOD C. L. (1995) A Semiotic Approach to Determining the Sins and Virtues Portrayed in Advertising en Journal of Current Issues and Research in Advertising, volumen 17, nº 1, págs 33-47.

LEISS, W. (1986) Social Communication in Advertising: Persons, Products and Images of Well Being. New York: Methuen.

LEÓN, J.L. (2001) Mitoanálisis de la Publicidad. Madrid. Ariel.

POLLAY, R. W. (1984) The Identification and Distribution of Values Manifest in Print Advertising 1900-1980 en Personal Values and Consumer Behavior, A.G. Woodsode and R. Pitts, eds. Lexington, MS. Lexington Books, págs 111-135. 
POLLAY, R. W. (1986) The Distorted Mirror: Reflections on the Unintended Consequences of Advertising en Journal of Marketing, nº 50 págs 18-36.

SCHUDSON, M. (1984) Advertising, The Uneasy Persuasion: Its Dubious Impact on American Society. New York. Basic Book.

SISSORS, J. (1978) Another Look at the Question: Does Advertising Affect Values en Journal of Advertising $n^{\circ} 3$, págs 26-30.

TANAKA, H. (1984) Cultural Values in U.S. and Japanese Magazine Advertising: A Comparative Content Analysis en Unpublished Master's Thesis, Suthern Illinois University. Webster's Third New International Dictionary /1976). Springfield, MA: G \& C Merriam Publising Co.

\section{ZALTMAN,G; WALLEDORF, M (1983) Consumer Behavior:Basic Findings and Management} Implications. New York: John Wiley and Sons.

www.publitv.com Los spots han sido tomados de la página señalada, con el único fin de utilización didáctica para argumentar los conceptos que se presentan. Agradecemos a los gestores de dicha página el acceso gratuito a dicha información. 